\title{
Investigation of sewage contamination using steroid indexes in sediments of the Guajará Estuary (Amazon coast, Brazil)
}

\author{
Heyde Gonçalves Gomes ${ }^{1}$, Silvia Keiko Kawakamil,*, Satie Taniguchi², Pedro Walfir Souza Filho ${ }^{1}$, \\ Rosalinda Carmela Montone ${ }^{2}$
}

\author{
${ }^{1}$ Faculdade de Oceanografia, Instituto de Geociências, Universidade Federal do Pará. \\ (Av Augusto Corrêa, 1, CEP: 66075-110, Campus do Guamá, Belém, Pará) \\ ${ }^{2}$ Departamento de Oceanografia Física, Instituto Oceanográfico, Universidade de São Paulo. \\ (Praça do Oceanográfico, 191, CEP: 05508-900, Cidade Universitária, São Paulo, São Paulo) \\ *Corresponding author: skawakami@ufpa.br
}

Financial Support: CAPES

\begin{abstract}
Amazonian aquatic systems are usually associated with pristine waters, however, irregular urban occupation of the hydrographic basins and sewerage deficiencies may lead to point and diffuse contamination. Sewage contamination in intertidal surface sediments from the Guajará Estuary, Brazilian Amazon coast, was evaluated using a set of steroids as biomarkers. Sediments collected along the urbanized margin were also analyzed for chlorophyll $a$, total organic carbon and grain sizes. Coprostanol, the main fecal sterol, was found at concentrations varying from 0.06 to $7.93 \mu \mathrm{g} \mathrm{g}^{-1}$ dry sediment, following the sequence Tucunduba $>$ Ver-o-Peso > Porto da Palha > Tamandaré > Icoaraci $>$ Miramar. Mixed sources of organic matter and coastal process probably concurred to produce weak correlations among the parameters. Plant derived sterols, including $n$-C30 alcohol and $\beta$-amyrinyl alkanoates, were clearly abundant, but they did not preclude the use of other steroid signals to the assessment of sewage contamination. High values of the steroid indexes involving $5 \alpha$ and $5 \beta$ stanols and stanones highlighted sewage contamination at the sites with the lowest absolute coprostanol concentrations. The predominance of $5 \beta$ stanols indicated a chronically sewage contamination of the area.
\end{abstract}

Descriptors: Coprostanol, Sewage, Guajará Estuary, Sitosterol, Amazon Coast, Mangrove swamps.

\section{RESUmo}

Os sistemas aquáticos amazônicos são geralmente associados a águas intactas, no entanto, a ocupação urbana de forma irregular das bacias hidrográficas e a deficiência no saneamento básico podem levar a contaminação pontual e difusa. A contaminação por esgoto em sedimentos superficiais de entremarés do Estuário Guajará, costa amazônica brasileira, foi investigada usando um conjunto de esteróides como biomarcadores. Os sedimentos coletados ao longo da margem urbanizada também foram submetidos a análises de clorofila- $a$, carbono orgânico total e granulometria. Coprostanol, o principal esterol de origem fecal, foi encontrado em concentrações entre 0,06 a 7,93 $\mu \mathrm{g} \mathrm{g}^{-1}$ de sedimento seco, na sequência Tucunduba $>$ Ver-o-Peso $>$ Porto da Palha $>$ Tamandaré $>$ Icoaraci $>$ Miramar. As baixas correlações entre os parâmetros investigados provavelmente foram resultantes de fontes mistas de matéria orgânica e processos costeiros. Os esteróis derivados de plantas, incluindo álcoois $n-\mathrm{C} 30 \mathrm{e}$ $\beta$-amirinil alcanoatos, mostraram-se abundantes nas amostras, porém não impediram o uso dos outros esteróides na avaliação da contaminação por esgoto. Índices específicos envolvendo estanóis e estanonas $5 \alpha$ and $5 \beta$ evidenciaram a contaminação por esgoto nas amostras com as menores concentrações absolutas de coprostanol. A predominância de estanóis $5 \beta$ indicou contaminação crônica por esgoto na área.

Descritores: Coprostanol, Esgoto, Estuário Guajará, Sitosterol, Costa Amazônica, Mangue. 
Amazonian aquatic ecosystems are usually associated with pristine environments because of the reduced industrial and urban development, the typical fluvialdominated hydrodynamics and the intense rains that have depuration and dilution effects on sewage effluents. The Brazilian Amazon coast like many coastal areas worldwide is subject to anthropic influence. The Guajará Estuary is an example of an Amazonian coastal area that serves multiple purposes. It is located at the mouth of the Amazon delta and is part of the Marajó Gulf system, in the State of Pará, North Brazil. The estuary receives around $6 \times 10^{3} \mathrm{~m}^{3}$ day $^{-1}$ of raw sewage both from its catchment area and from the coast produced by commercial and touristic activities (IBGE, 2010) related mainly to the Ver-o-Peso open fish market, the Miramar oil terminal, several dockyards, fish processing industries and kaolin and other chemical processing industries which contribute with a variety of effluent discharges. The capital of Pará, Belém, alone accounts for a population of around $1.40 \times 10^{6}$ inhabitants (IBGE, 2010), the highest on the north coast. According to the latest IBGE report, 54.5\% of the population of the Belém metropolitan region resides in illegal areas and part of the low-income population lives along the coast in stilt houses in areas subject to flooding with no access to sanitary infrastructure. The sewerage systems of the suburbs and central districts dispose of the wastes directly into the bay or via channels and rivers with no prior treatment.

Despite the precarious sanitary conditions of the area, there is still a paucity of studies on the identification and monitoring of sewage organic contamination that could help to prevent potential adverse effects to both public health and environmental quality standards. Alternative indicators derived from cholesterol such as coprostanol, epicoprostanol, cholestanol, coprostanone and cholestanone have been applied for the identification of the chemical composition of sedimentary organic matter and particularly for tracking sewage contamination in diverse environments (GRIMALT et al., 1990; VENKATESAN; MIRSADEGHI, 1992; EGANHOUSE; SHERBLOM, 2001; MARTINS et al., 2008; COSTA et al., 2011). Cholesterol is reduced by bacteria in the intestinal tract of most mammals and birds resulting in coprostanol, the main fecal sterol (BULL et al., 2002). In human feces, coprostanol constitutes $60 \%$ of the total sterols (LEEMING et al., 1996). Because steroids are hydrophobic they tend to adsorb to sewage particulate matter and during sinking and burial these compounds undergo degradation or are eventually preserved in anoxic sediments depending on the ambient conditions and sediment re-working (PRATT et al., 2008).

The steroidal composition of the Amazonian estuarine sediments has been related to its abundant mangrove vegetation (KOCH et al., 2011), part of the second largest mangrove belt in the world (MENEZES et al., 2008). Mangrove leaves and roots contain a large number of sterols and triterpenes (GHOSH et al., 1985; BASYUNI et al., 2007) and make an important contribution to the carbon biogeochemistry of coastal environments. In the present study, selected steroids from both fecal and plant sources were examined in the intertidal surface sediments of the Guajará Estuary (Belém, Pará). Our study is the first to address an investigation of sewage biomarkers in an Amazonian estuarine system.

The Guajará Estuary $\left(01^{\circ} 27^{\prime} \mathrm{S} 48^{\circ} 30^{\prime} \mathrm{W}\right)$ receives hydrodynamic and sedimentary contributions from the Guamá and Acará-Moju rivers, forming an oligohaline, highly dynamic, mixed-energy fluvial dominated system with a semidiurnal mesotidal regime and spring tidal variations of around $3.6 \mathrm{~m}$ and surface current during ebb spring tide of up to $2.2 \mathrm{~m} \mathrm{~s}^{-1}$ (GREGÓRIO; MENDES, 2009). The ebb and flood channels are positioned, respectively, on the left and right margins of the estuary, with shallower depths and sandy mud banks predominating on the urbanized right margin (GREGÓRIO; MENDES, 2009). The Köppen-Geiger climatic classification is type Af, equatorial with temperatures ranging from 27 to $32^{\circ} \mathrm{C}$, and humidity around $70-80 \%$. Seasons are marked by wet (December to March) and dry (April to November) periods. Mean precipitation for January/2011 reached $525 \mathrm{~mm}$ (INMET, 2012). The mangrove vegetation is dominated by Rhizophora racemosa, Rhizophora mangle, Avicennia germinans and, to a lesser extent, Laguncularia racemosa (MENEZES et al., 2008).

Sediment samples from 6 intertidal sites were collected using a stainless steel spatula, in January/2011, along the urbanized margin of the estuary, and named after the nearest towns or rivers: Tucunduba, Tamandaré, Ver-o-Peso, Porto da Palha, Miramar and Icoaraci (Table 1). The sites were chosen due to the use of the surrounding waters for primary and secondary contact. Sediments were sub-sampled for analyses of steroids, grain size, total organic carbon and chlorophyll $a$. Steroids were analyzed as trimethyl silyl ether derivatives by gas chromatography with flame ionization detection (KAWAKAMI; MONTONE, 2002) and confirmed by mass spectrometry. Chromatographic separation was 
performed using a 5\% phenyl-methyl-silicon column (50 $\mathrm{m}, 0.32 \mathrm{~mm}$ external diameter and $0.17 \mathrm{~mm}$ internal diameter). Mass spectra were obtained using the same separation conditions and operated in the electron impact mode at $70 \mathrm{eV}$, scan for spectra acquisition, with helium as carrier gas. Sample mass spectra were compared with analytical standards and literature data. Complete procedural blanks were performed to check for cross contamination. Recoveries ranged from 84 to $89 \%$ ( $5 \alpha$-cholestane). Grain sizes were determined using a laser granulometer and Sysgran software after elimination of organic carbon with hydrogen peroxide (SUGUIO, 1973; CAMARGO, 2006). Chlorophyll- $a$ was determined using a well-established spectrophotometric method based on 90\% acetone extraction (PARSONS et al., 1984). Total organic carbon (TOC) was analysed by a titrimetric method using potassium dichromate with ammonium ferrous sulphate and diphenylamine (GAUDETTE et al., 1974). The hydrochemical parameters of the overlying waters $(\mathrm{pH}$, temperature, salinity, conductivity, and total dissolved solids) were measured in situ using a portable analyser (Table 1).

Coprostanol, epicoprostanol, cholesterol, coprostanone, cholestanone, brassicasterol, stigmasterol and $n$-alkanols $(n=27-30)$ were identified in the sediment samples of the Guajará Estuary by GC-FID retention times and their prominent $\mathrm{m} / \mathrm{z}$ values from authentic standards or comparisons with literature data. A typical GC-FID chromatogram profile is illustrated for the sediment samples in Figure 1. It was found that some compounds coeluted with sitosterol and sitostanol. The saponification step was not performed during extraction, therefore plant waxes presumably esters coeluted with sitosterol as indicated by $\mathrm{m} / \mathrm{z}$-values for key mass fragments of $\beta$-amyrinyl alkanoates (Figure 2a). Amyrinyl has been identified as an abundant compound in epicuticular wax in leaves of Rhizophora mangle and riverine sediments (OYO-ITA et al., 2010). Long-chain $n$-alkanols with more than 20 units of C atoms (SIMONEIT, 1986; FERNANDES et al., 1999) did not appear to cause interference on sterol analyses, except $n$-C30 alcohol that co-eluted with sitostanol (Figure 2b), as indicated by the $\mathrm{m} / \mathrm{z}$ profile of the sediment samples. Other mangrove derived triterpenoids usually found in sediments such as $\beta$-amyrin, $\alpha$-amyrin, germanicol, taraxerol, lupeol, and butelin (GHOSH et al., 1985; KOCH et al., 2003; $\mathrm{KOCH}$ et al., 2011) were not identified as causing any interference according to comparisons with literature $\mathrm{m} / \mathrm{z}$ fragmentation profiles.

An analytical method for the mangrove derived $n$-alkanols and triterpenoids was not optimized and therefore these compounds were not quantified. Apart from cholestanone, other stanones such as taraxerone, oleanones, ursenones and hopanones, reported in eutrophic areas (GRIMALT et al., 1990), have not been evaluated. On the other hand, sitosterol, sitostanol, brassicasterol and cholestanol, which are phytosterols, were quantified to

Table 1. Ancillary hydrochemical and sedimentary parameters for the Guajará Estuary, with sampling positions.

\begin{tabular}{|c|c|c|c|c|c|c|}
\hline Ancillary data & $\begin{array}{c}\text { Tucunduba } \\
\text { Site } 1\end{array}$ & $\begin{array}{l}\text { Porto da Palha } \\
\quad \text { Site } 2\end{array}$ & $\begin{array}{c}\text { Tamandaré } \\
\text { Site } 3\end{array}$ & $\begin{array}{l}\text { Ver-o-Peso } \\
\text { Site } 4\end{array}$ & $\begin{array}{l}\text { Miramar } \\
\text { Site } 5\end{array}$ & $\begin{array}{c}\text { Icoaraci } \\
\text { Site } 6\end{array}$ \\
\hline Location & $\begin{array}{l}\text { S01 }{ }^{\circ} 18^{\prime} 01.3^{\prime \prime} \\
\text { W 48 } 48^{\circ} 29^{\prime} 25.8^{\prime \prime}\end{array}$ & $\begin{array}{l}\mathrm{S} 01^{\circ} 18^{\prime} 01.3^{\prime \prime} \\
\mathrm{W} 48^{\circ} 29^{\prime} 25.8^{\prime \prime}\end{array}$ & $\begin{array}{l}\mathrm{S} 01^{\circ} 18^{\prime} 01.3^{\prime \prime}, \\
\mathrm{W} 48^{\circ} 29^{\prime} 25.8^{\prime \prime}\end{array}$ & $\begin{array}{l}\text { S01 }{ }^{\circ} 18^{\prime} 01.3^{\prime \prime}, \\
\text { W } 48^{\circ} 29^{\prime} 25.8^{\prime \prime}\end{array}$ & $\begin{array}{l}\text { S01 }{ }^{\circ} 18^{\prime} 01.3^{\prime \prime} \\
\text { W 48 } 48^{\circ} 29^{\prime} 25.8^{\prime \prime}\end{array}$ & $\begin{array}{l}\text { S01 }{ }^{\circ} 18^{\prime} 01.3^{\prime \prime}, \\
\text { W } 48^{\circ} 29^{\prime} 25.8^{\prime \prime}\end{array}$ \\
\hline \multicolumn{7}{|l|}{ Hydrochemical } \\
\hline $\mathrm{pH}$ & 6.57 & 6.26 & 6.64 & 6.23 & 6.43 & 6.67 \\
\hline Temperature $\left({ }^{\circ} \mathrm{C}\right)$ & 28.9 & 29.5 & 28.7 & 29.1 & 29.2 & 29.5 \\
\hline $\begin{array}{l}\text { Total dissolved solids } \\
\left(\mathrm{mg} L^{-1}\right)\end{array}$ & 41.0 & 32.0 & 45.0 & 39.0 & 45.0 & 51.0 \\
\hline Salinity & 0.0 & 0.0 & 0.0 & 0.0 & 0.0 & 0.1 \\
\hline $\begin{array}{l}\text { Conductivity } \\
\left.(\mu \mathrm{S} \mathrm{cm})^{-1}\right)\end{array}$ & 87.8 & 68.3 & 96.5 & 83.2 & 95.5 & 108.2 \\
\hline \multicolumn{7}{|l|}{ Sediment } \\
\hline $\begin{array}{l}\text { Chlorophyll } a \\
\text { (mg g }{ }^{-1} \text { dry sediment) }\end{array}$ & 0.52 & 2.41 & 1.07 & $\mathrm{Nd}$ & 0.43 & 0.40 \\
\hline TOC (\%) & 15.5 & 4.0 & 3.0 & - & 3.5 & 15.9 \\
\hline Sand (\%) & 6.9 & 19.1 & 13.3 & 97.6 & 0.0 & 16.4 \\
\hline Silt (\%) & 76.1 & 71.4 & 70.3 & 1.7 & 77.6 & 60.9 \\
\hline Clay (\%) & 17.0 & 9.5 & 16.4 & 0.7 & 22.4 & 22.7 \\
\hline
\end{tabular}




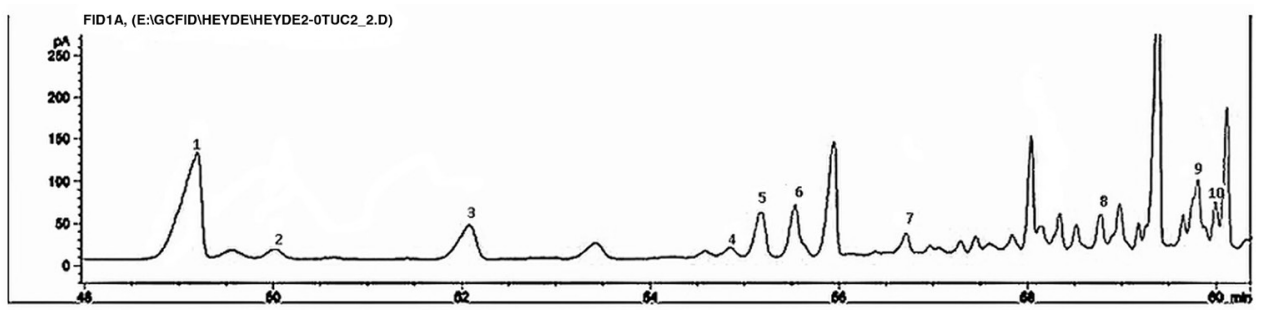

Figure 1. Typical GC-FID profile of the sediment sample from Tucunduba. Peak identification: 1. Coprostanol; 2. Epicoprostanol; 3. Coprostanone; 4. Cholestanone; 5. Cholesterol; 6. Cholestanol; 7. Brassicasterol; 8. Stigmasterol; 9. $\beta$-Sitosterol; 10. $\beta$-Sitostanol.

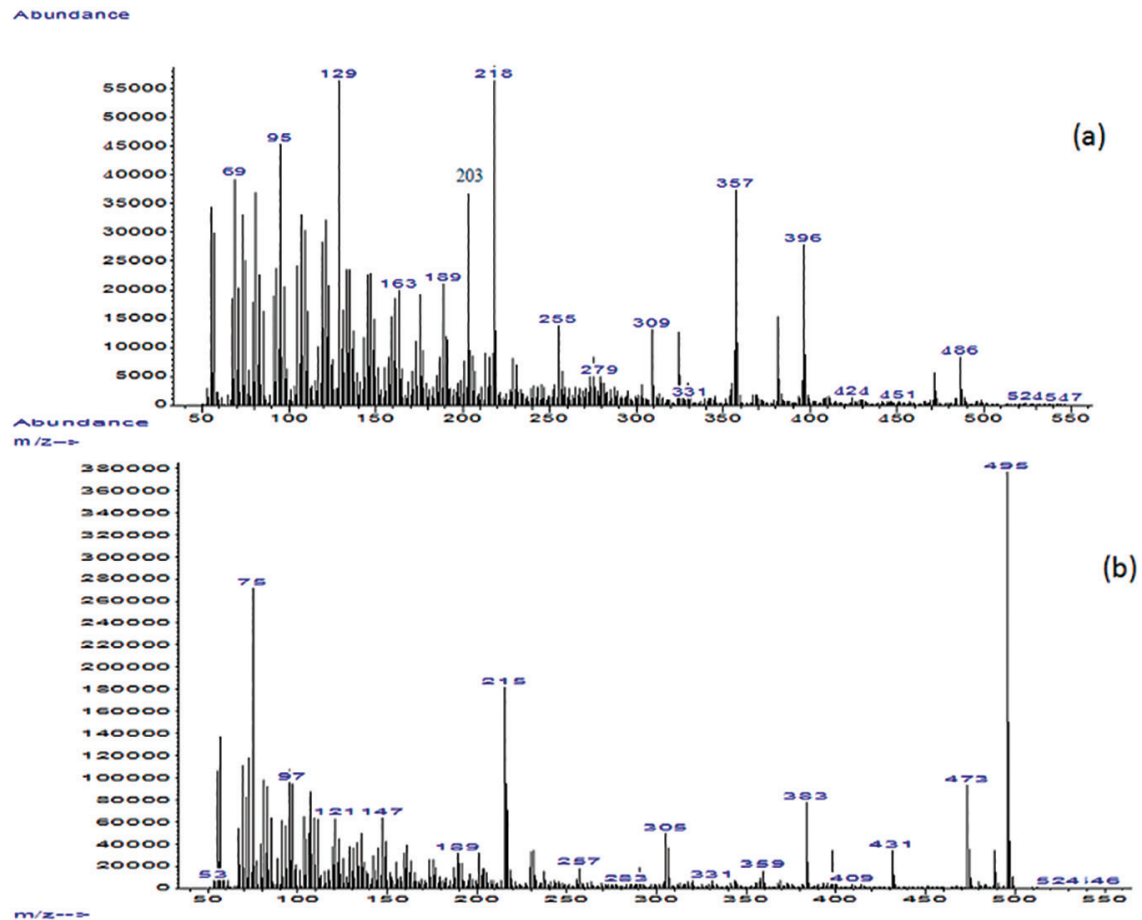

Figure 2. Typical mass fragmentograms obtained for sediment samples from the Guajará Estuary indicating: (a) coelution of $\beta$-amyrinyl (m/z: 218, 203, 189) with sitosterol (m/z: 129, 357, 396, 486); (b) coelution of $n$ - $\mathrm{C}_{30}$ alcohol (m/z: 495) with sitostanol (m/z: 107, 147, 215, 383, 473).

allow a comparison of the natural organic sources and a better understanding of the composition of the estuarine sediments.

The concentrations of the steroids, together with the contents of chlorophyll a, total organic carbon, and granulometry are presented in Table 2 . The total steroids concentrations ranged from 8.76 to $57.3 \mu \mathrm{g} \mathrm{g}^{-1}$ dry sediment, with highest value at site 4 (Ver-o-Peso). Coprostanol, the main fecal sterol, was found at concentrations varying from 0.06 to $7.93 \mu \mathrm{g} \mathrm{g}^{-1}$ dry sediment, following the sequence Tucunduba $>$ Ver-o-Peso $>$ Porto da Palha $>$ Tamandaré $>$ Icoaraci $>$ Miramar. Coprostanol concentrations higher than $0.010 \mu \mathrm{g} \mathrm{g}^{-1}$ in marine sediments have been taken as an indication of sewage contamination from urban or livestock sources (HATCHER; MCGILLIVARY, 1979). Based on the absolute coprostanol concentrations, the sediments of the Guajará Estuary are under sewage influence comparable to that of other contaminated coastal ecosystems (GRIMALT et al., 1990; VENKATESAN; KAPLAN, 1990; MUDGE; BEBIANO, 1997; EGANHOUSE; SHERBLOM, 2001; MARTINS et al., 2008).

Epicoprostanol corresponded to $0.2-6.4 \%$ of total steroids and is probably a result of diagenetic transformations since considerable amounts of this sterol in recent sediments are recorded only when urban sewage sludge undergoes digestion treatment (MCCALLEY 
Table 2. Concentrations of steroids in sediment samples from the Guajará Estuary. Values between parentheses indicate percentage to total steroids

\begin{tabular}{|c|c|c|c|c|c|c|}
\hline Steroid $\left(\mu \mathbf{g ~ g}^{-1}\right)$ & $\begin{array}{l}\text { Tucunduba } \\
\text { Site } 1\end{array}$ & $\begin{array}{l}\text { Porto da Palha } \\
\quad \text { Site } 2\end{array}$ & $\begin{array}{c}\text { Tamandaré } \\
\text { Site } 3\end{array}$ & $\begin{array}{l}\text { Ver-o-Peso } \\
\text { Site } 4\end{array}$ & $\begin{array}{l}\text { Miramar } \\
\text { Site } 5\end{array}$ & $\begin{array}{l}\text { Icoaraci } \\
\text { Site } 6\end{array}$ \\
\hline 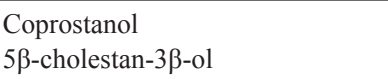 & 7.93 (33.9) & $1.37(3.0)$ & $1.03(14.7)$ & $5.61(9.8)$ & $0.06(0.2)$ & $0.19(2.2)$ \\
\hline $\begin{array}{l}\text { Epicoprostanol } \\
5 \beta \text {-cholestan-3 } 3 \text {-ol }\end{array}$ & $0.62(2.6)$ & $1.92(4.2)$ & $0.15(2.1)$ & $3.65(6.4)$ & $0.05(0.2)$ & $0.04(0.5)$ \\
\hline $\begin{array}{l}5 \beta \text {-coprostanone } \\
5 \beta \text {-cholestan-3-one }\end{array}$ & $2.35(10.0)$ & $11.0(23.9)$ & $0.46(6.6)$ & $3.53(6.2)$ & $0.16(0.6)$ & $0.23(2.6)$ \\
\hline $\begin{array}{l}5 \alpha \text {-cholestanone } \\
5 \alpha \text {-cholestan-3-one }\end{array}$ & $0.52(2.2)$ & $5.16(11.2)$ & $0.13(1.9)$ & $1.19(2.1)$ & $0.02(0.1)$ & $0.20(2.3)$ \\
\hline $\begin{array}{l}\text { Cholesterol } \\
\text { Cholest-5-en-3 } \beta \text {-ol }\end{array}$ & $2.51(10.7)$ & $5.82(12.7)$ & $0.71(10.1)$ & $16.9(29.6)$ & $0.54(1.9)$ & $1.34(15.3)$ \\
\hline $\begin{array}{l}\text { Cholestanol } \\
5 \alpha \text {-cholestan-3 } \beta \text {-ol }\end{array}$ & $2.19(9.4)$ & $6.50(14.1)$ & $0.88(12.6)$ & $9.17(16.0)$ & $1.53(5.3)$ & $1.14(13.0)$ \\
\hline $\begin{array}{l}\text { Brassicasterol } \\
24 \text {-methylcholest-5,22-dien-3 } \beta \text {-ol }\end{array}$ & $0.99(4.2)$ & $3.06(6.7)$ & $0.19(2.7)$ & $3.01(5.3)$ & $0.32(1.1)$ & $0.46(5.2)$ \\
\hline $\begin{array}{l}\text { Stigmasterol } \\
\text { 24-ethylcholest-5,22-dien-3 } \beta \text {-ol }\end{array}$ & $2.32(10.0)$ & $5.25(11.4)$ & $0.29(4.1)$ & $5.96(10.4)$ & $2.89(10.0)$ & $1.97(22.5)$ \\
\hline $\begin{array}{l}\beta \text {-sitosterol* } \\
\text { 24-ethylcholest-5-en-3 } \beta \text {-ol }\end{array}$ & $2.43(10.4)$ & $3.10(6.7)$ & $1.37(19.6)$ & $3.07(5.4)$ & $6.84(23.7)$ & $2.00(22.8)$ \\
\hline $\begin{array}{l}\beta \text {-sitostanol* } \\
24 \text {-ethyl-5 } \alpha \text {-cholestan-3 } \beta \text {-ol }\end{array}$ & $1.59(6.8)$ & $2.89(6.3)$ & $1.79(25.6)$ & $5.17(9.0)$ & $16.5(56.9)$ & 1.19 (13.6) \\
\hline Total steroids & 23.4 & 46.0 & 7.00 & 57.3 & 28.9 & 8.76 \\
\hline
\end{tabular}

et al., 1981), which is not the case for the study area in question. Furthermore, site 2 (Porto da Palha) was the only site for which epicoprostanol concentration was superior to that of coprostanol. A diagenetic interconversion of coprostanol into epicoprostanol via coprostanone, a process known as epimerisation, may also occur as observed in laboratory experiments with sewage sludge (MCCALLEY et al., 1981).

Elevated $5 \beta$-coprostanone concentrations were found in samples from Tucunduba, Ver-o-Peso, and exceptionally high ones at site 2 (Porto da Palha, 24\% of total steroids). Site 2 also presented high concentration of $5 \alpha$-cholestanone ( $11 \%$ of total steroids) and evidenced, as epicoprostanol, the occurrence of diagenetic transformations assuming that the $5 \alpha$ compounds correspond to the thermodynamic products (LEEMING et al., 1996). 5 $\beta$-coprostanone intermediates the intestinal transformation of cholesterol into coprostanol and the combinations of the concentration ratios involving $5 \beta$-coprostanone, $5 \alpha$-cholestanone, coprostanol and cholestanol have been considered a more reliable indication of fecal contamination, particularly when coprostanol levels alone can be masked by mixed sources of fecal material other than that from humans (GRIMALT et al., 1990; BULL et al., 2002; PRATT et al., 2008). The use of steroid ratios is presented later in the next topic.
Cholesterol (2-30\% of the total steroids) and cholestanol (5-16\% of total steroids) were found in their highest concentrations at site 4 (Ver-o-Peso). Cholesterol is also produced by marine organisms (VOLKMAN, 2005), whereas cholestanol is present in several organisms including phytoplankton, zooplankton, water weed, and terrestrial higher plants (NISHIMURA; KOYAMA, 1977). These sterols can also be found in feces in different proportions and depend on the animals concerned and their dietary habits (LEEMING et al. 1996; SHAH et al. 2007), care should, therefore be taken when considering only these compounds as biomarkers of marine or terrestrial organic inputs in areas under anthropogenic impact.

Brassicasterol was observed at its lowest concentrations (1-7\% of total steroids), which is in line with the weak marine influence throughout the estuary as this phytosterol is mostly to be expected in marine phytoplankton cells, although it can also be produced by some terrestrial plants (VOLKMAN, 2005). In constrast, stigmasterol (4-23\% of total steroids) and sitosterol (5-24\% of total steroids) were found widespread and at high concentrations. Sitosterol and stigmasterol are predominantly of terrestrial origin, but cannot be unequivocally used as terrestrial biomarkers as they can be synthesized by some phytoplankton 
species (VOLKMAN, 2005). Nevertheless, such high concentrations are consistent with the abundance of vascular plants and organic debris (VOLKMAN, 2005; $\mathrm{KOCH}$ et al., 2011) in the proximity of the sampling sites, particularly at sites 5 (Miramar) and 6 (Icoaraci).

Chlorophyll $a$ was found in all sediment samples but that from site 1 (Ver-o-Peso), where the lowest clay percentage was observed. Because the sediment-water interface is usually an active diagenetic layer, the accumulation of chlorophylls presenting intact structures is also an indication of a depositional environment undergoing slow organic degradation (KILLOPS; KILLOPS, 2005). Enhanced phytoplankton primary productivity and an increase in chl a concentrations in tropical creeks have been associated with sewage inputs (BURFORD et al., 2012), however in the present case sedimentary chl a is probably derived from the abundant surrounding terrestrial plants. High concentrations of suspended particulate matter in the Guajará Estuary, particularly during the rainy season may represent an inhibiting factor for phytoplankton growth. Low significant linear correlations were observed for the variables TOC \%, fecal steroids, chl a and phytosterols that could clarify the relationships. As may also be seen, for instance, in observations made in other tropical estuaries (CORDEIRO et al., 2008; MARTINS et al., 2008), no significant correlations between $\operatorname{mud}(\%)$ and steroids were apparent - probably a result of multiple organic sources and coastal processes.

Comparisons using the absolute concentrations of steroids are not always conclusive for the evaluation of the degree of organic contamination as differences in TOC and grain size have effects on the adsorption, accumulation and preservation of organic matter (GRIMALT et al., 1990; AKHURST et al., 2011). Furthermore, the presence of fecal matter from animals other than humans may compromise the interpretation of the results. For instance, substantial quantities of coprostanol in feces of birds, herbivores and carnivores could hamper the use of steroids as human sewage markers (LEEMING et al., 1996; SHAH et al., 2007). Therefore a number of indexes using ratios of coprostanol to other steroids have been proposed to minimize the dependence of the steroid analyses on sediment variables and also to discriminate sources of human and non-human fecal contamination in catchment waters and sediments (GRIMALT et al., 1990; LEEMING et al., 1996; SHAH et al., 2007).

For highly productive areas the use of indexes involving not only $5 \beta$ and $5 \alpha$ stanols but also indexes with stanones has been recommended (GRIMALT et al., 1990; MUDGE;
NORRIS, 1997). A combination of the indexes is presented in Figure $3 \mathrm{a}$ and highlights sewage contamination, particularly for Miramar and Icoaraci, the sites with the lowest absolute coprostanol concentrations. Values of $[5 \beta$-coprostanone $/(5 \beta+5 \alpha$-cholestanone $)]>0.7$ support the indication of sewage contamination for sediments from sites 1, 3, 4 and 5 (Tucunduba, Tamandaré, Ver-o-Peso and Miramar), whereas values lower than 0.7 suggest mixed organic sources for sites 2 and 6 (Porto da Palha and Icoaraci). These latter sites, however, can also be considered chronically or recently contaminated by sewage because of the values of the ratio [coprostanol/epicoprostanol] > 1.0 ; indicating a slow rate of epimerisation of coprostanol (MCCALLEY et al., 1981).

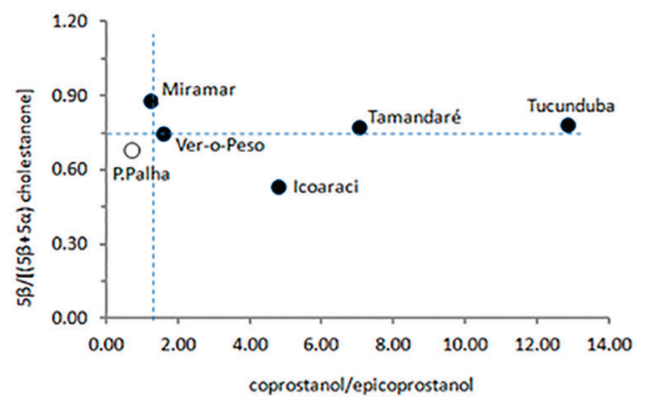

(a)

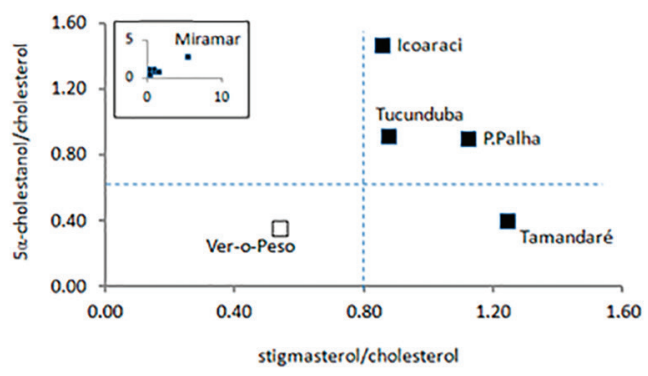

(b)

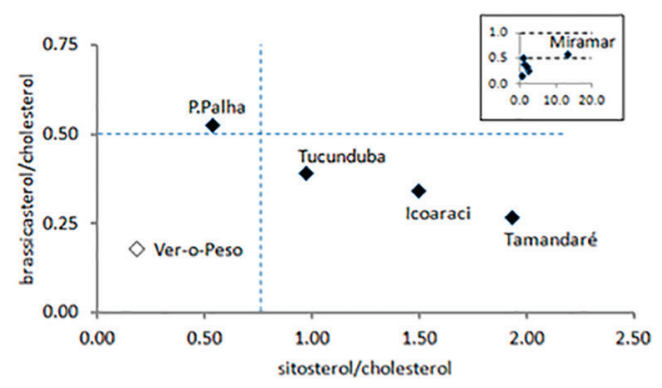

(c)

Figure 3. Sources of sedimentary steroids to the Guajará Estuary emphasized by cross-plots (a) sewage inputs by the steroid

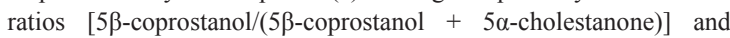
[coprostanol/epicoprostanol]; (b) contribution from vascular plants by the ratios (stigmasterol/cholesterol) and (5 $\alpha$-cholestanol/cholesterol); and (c) contribution from algae and mangrove by the ratios (brassicasterol/cholesterol) and (sitosterol/cholesterol). Sitosterol is the sum of sitosterol and amyrinyl. 
The study area is predominantly urbanized, as confirmed by the State's most recent mapping of land use (IDESP, 2011), the activities involving livestock and animal manures have probably not led to any considerable interference in coastal sedimentary steroids. Furthermore, the Tucunduba and Tamandaré channels belong to hydrographic systems that constitute the catchment areas of important districts whose waste treatment plants and primary sewerage systems have not yet been fully implemented. Site 1 (Ver-o-Peso) is located in front of the largest Brazilian fish open market and is subject to the constant traffic of boats that trade fishes and other small animals, fruits, and herbs harvested on the nearby islands or brought from the south of the State. It is clear to the observer that part of the residues produced at this site is discharged directly into the water, which probably contributed to the highest concentrations of total sterols found.

It is worth noting that the activities undertaken at Vero-Peso and Porto da Palha attract a large number of birds such as vultures and, to a lesser extent, herons, which possibly contribute with additional inputs of cholesterol and coprostanol as these birds are carnivores and feed on dumped fish residues and other animal detritus. SHAH et al. (2007) estimated that chickens, which may be taken to provide a rough comparison as such birds do not feed exclusively on animals detritus, contribute substantially to the cholesterol and sitosterol of the total fecal steroids (with, respectively, 20 and 60\%). An attempt to characterize fecal contamination in riverine systems from different sources has been presented by PUERARI et al. (2012) based on ternary plots using data from LEEMING and NICHOLS (1996) and distinguishing contributions from pigs, horses and cows. To the best of our knowledge, there are no data regarding the fecal steroid composition of vultures and herons that could provide a more detailed assessment of these sources in Ver-o-Peso and Porto da Palha.

A remarkable occurrence of steroids from natural organic sources using specific indexes is confirmed throughout the estuary by the ratios [stigmasterol/ cholesterol] $>0.6$ and [5 $\alpha$-cholestanol/cholesterol] $>$ 0.8 , illustrated in Figure $3 \mathrm{~b}$. Both indexes emphasize the contribution from vascular plants and are in accord with the presence of mangrove species in the vicinities of the sites. The indexes' values were low only for the sediments from site 4 (Ver-o-Peso). Steroids originating from algae can be identified by low values of the ratio [stigmasterol/ brassicasterol], as brassicasterol appears to be common in various phytoplankton species (VOLKMAN, 2005). Contribution from mangroves is also reflected by the high values of [sitosterol/cholesterol] (Figure 3c). Site 2 (Porto da Palha) was the only site where the contribution from phytoplankton was evident, whereas site 4 (Ver-o-Peso) was observed to be the least influenced by steroid inputs from mangroves, consistently with the results indicated by the above ratios of stigmasterol and cholestanol.

There is a paucity of literature data regarding the sewage contamination of Amazonian aquatic systems, although the sanitary infrastructure problems faced by the population of North Brazil are still considered the worst in the country. In summary, despite the strong hydrodynamics, coprostanol, cholesterol and coprostanone were found in all the sediment samples of the Guajará Estuary and indicated contamination indexes comparable to those of highly impacted coastal areas worldwide. Higher plant-derived steroids, including $n$-C30 alcohol and $\beta$-amyrinyl alkanoates, were clearly abundant, as was to be expected for a highly productive area, but did not interfere in the fecal steroid analysis for the assessment of organic contamination.

\section{ACKNOWLEDGEMENTS}

We are grateful to Coordenação de Apoio à Pesquisa de Ensino Superior (CAPES) for the MSc grant and financial support for $\mathrm{H}$. Gomes. We thank $\mathrm{Mr}$ Afonso Quaresma and Gustavo Miranda for their kind help with sampling and the comments from the reviewer.

\section{REFERENCES}

AKHURST, D. J.; CLARK, M. W.; REICHELT-BRUSHETT, A.; JONES, G. B. Grain size normalization: a case for post extraction normalization and inclusion of selective extraction procedures. Limnol. Oceanogr. Methods, v. 9, n. 5, p. 215231, 2011.

BASYUNI, M.; OKU, H.; BABA, S.; TAKARA, K.; IWASAKI, $\mathrm{H}$. Isoprenoids of Okinawan mangroves as lipid input into estuarine ecosystem. J. Oceanogr., v. 63, n. 4, p. 601-608, 2007.

BULL, I. A.; LOCKHEART, M. J.; ELHMMALI, M. M.; ROBERTS, D. J.; EVERSHED, R. P. The origin of faeces by means of biomarker detection. Environ. Int., v. 27, n. 8, p. $647-654,2002$.

BURFORD, M. A.; REVILL, A. T.; SMITH, J.; CLEMENTSON, L. Effect of sewage nutrients on algal production, biomass and pigments in tropical tidal creeks. Mar. Pollut. Bull., v. 64, n. 12 , p. 2671-2680, 2012.

CAMARGO, M. G. Sysgran: um sistema de código aberto para análises granulométricas do sedimento. Rev. Bras. Geociênc., v. 36, n. 2, p. 371-378, 2006. 
CORDEIRO, L. G. S. M.; CARREIRA, R. S.; WAGENER, A. L. R. Geochemistry of fecal sterols in a contaminated estuary in southeastern Brazil. Org. Geochem., v. 39, n. 8, p. 10971103, 2008.

COSTA, T. L. F.; ARAÚJO, M. P.; KNOPPERS, B. A.; CARREIRA, R. S. Sources and distribution of particulate organic matter of a tropical estuarine-lagoon system from NE Brazil as indicated by lipid biomarkers. Aquat. Geochem., v. 17, n. 1, p. 1-19, 2011.

EGANHOUSE, R. P.; SHERBLOM, P. M. Anthropogenic organic contaminants in the effluent of a combined sewer overflow: impact on Boston Harbor. Mar. Environ. Res., v. 51, n. 1, p. 51-74, 2001.

FERNANDES, M. B.; SICRE, M. A.; CARDOSO, J. N.; MACÊDO, S. J. Sedimentary 4-desmethyl sterols and n-alkanols in an eutrophic urban estuary, Capibaribe River, Brazil. Sci. Total Environ., v. 231, n. 1, p. 1-16, 1999.

GAUDETTE, H. E.; FLIGHT, W. R; TONER, L.; FOLGER, D. W. An inexpensive tritation method for the determination of organic carbon in recent sediments. J. Sedim. Petrol., v. 44, n. 1, p. 249-253, 1974.

GHOSH, A.; MISRA, S.; DUTTA, A. K.; CHOUDHURY, A. Pentacyclic triterpenoids and sterols from seven species of mangrove. Phytochemistry, v. 24, n. 8, p. 1725-1727, 1985.

GREGÓRIO, A. M. S.; MENDES, A. C. Characterization of sedimentary deposits at the confluence of two tributaries of the Pará River estuary (Guajará Bay, Amazon). Cont. Shelf Res., v. 29, n. 3, p. 608-618, 2009.

GRIMALT, J. O.; FERNANDÉZ, P.; BAYONA, J. M.; ALBAIGÉS, J. Assessment of fecal sterols and ketones as indicators of urban sewage inputs to coastal waters. Environ. Sci. Technol., v. 24, n. 3, p. 357-363, 1990.

HATCHER, P. G.; MCGILLIVARY, P. A. Sewage contamination in the New York Bight. Coprostanol as an indicator. Environ. Sci. Technol., v.13, n.10, p. 1225-1229, 1979.

IBGE. Síntese de indicadores sociais. Uma análise das condições de vida da população brasileira. 2010. Estudos e Pesquisas. Rio de Janeiro: Informação demográfica e socioeconômica número 27, 2010. $317 \mathrm{p}$.

IBGE. Censo demográfico 2010. Características urbanísticas do entorno dos domicílios. Instituto Brasileiro de Geografia e Estatística. Rio de Janeiro: Ministério do Planejamento, Orçamento e Gestão, 2012. 175 p.

IDESP. Estado do Pará: (di) visões territoriais, perspectivas sociais, econômicas, financeiras e ambientais. Ocupação e uso do território, federalização territorial e recursos naturais. Lúcia Cristina Andrade (coord.). Belém: Instituto de Desenvolvimento Econômico, Social e Ambiental do Pará, 2011. $67 \mathrm{p}$.

INMET. Instituto Nacional de Meteorologia. Available at: $<$ www. inmet.gov.br> Accessed: 05/02/2012.

KAWAKAMI, S. K.; MONTONE, R. C. An efficient ethanol based analytical protocol to quantify faecal steroids in marine sediments. J. Braz. Chem. Soc., v. 2, p. 226-232, 2002.

KILLOPS, S.; KILLOPS, V. An Introduction to Organic Geochemistry. 2. ed. Oxford: Blackwell, 2005.
KOCH, B. P.; RULLKOTTER, J.; LARA, R. J. Evaluation of triterpenols and sterols as organic biomarkers in a mangrove ecosystem in northern Brazil. Wet. Ecol. Manag., v. 11, p. 257-263, 2003.

KOCH, B. P.; SOUZA FILHO, P. W. M.; BEHLING, H.; COHEN, M. C. L.; KATTNER, G.; RULLKÖTTER, J.; SCHOLZBÖTTCHER, B.; LARA, R. J. Triterpenols in mangrove sediments as a proxy for organic matter derived from the red mangrove (Rhizophora mangle). Org. Geochem., v. 42, n. 1, p. 62-73, 2011.

LEEMING, R.; BALL, A.; ASHBOLT, N.; NICHOLS, P. Using faecal sterols from humans and animals to distinguish faecal pollution in receiving waters. Wat. Res., v. 30, n. 12, p. 28932900, 1996.

LEEMING, R.; NICHOLS, P. D. Concentrations of coprostanol that correspond to existing bacterial indicator guideline limits. Wat. Res., v. 30, n. 12, p. 2997-3006, 1996.

MARTINS, C. C.; GOMES, F. B. A.; FERREIRA, J. A.; MONTONE, R. C. Marcadores orgânicos de contaminação por esgotos sanitários em sedimentos superficiais da baía de Santos, São Paulo. Quím. Nova, v. 31, n. 5, p. 1008-1014, 2008.

MCCALLEY, D. V.; COOKE, M.; NICKLESS, G. Effects of sewage treatment on faecal sterols. Wat. Res., v. 15, n. 8, p. 1019-1025, 1981.

MENEZES, M. P. M.; BERGER, U.; MEHLIG, U. Mangrove vegetation in Amazonia: a review of studies from the coast of Pará and Maranhão States, north Brazil. Acta. Amaz., v. 38, n. 3, p. 403-420, 2008.

MUdGE, S. M., BEBIANNO, M. J. Sewage contamination following an accidental spillage in the Rio Formosa, Portugal. Mar. Pollut. Bull., v. 34, n. 3, p.163-170, 1997.

MUDGE, S. M., NORRIS, C. E. Lipid biomarkers in the Conwy Estuary (North Wales, U.K.): a comparison between fatty alcohols and sterols. Mar. Chem., v. 57, n. 1, p. 61-84, 1997.

NISHUMURA, M; KOYAMA, T. The occurrence of stanols in various living organisms. Geochim. Cosmochim. Acta, 41, 379-385, 1977.

OYO-ITA, O. E.; EKPO, B. O.; OROS, D. R.; SIMONEIT, B. R. T. Occurrence and source of triterpenoid methyl ethers and acetates in sediments of the cross-river system, Southeast Nigeria. Int. J. Anal. Chem., v. 2010, 8 p., 2010.

PARSONS, T. R.; MAITA, Y.; LALLI, C. M. A manual of chemical and biological methods for seawater analysis. Oxford: Pergamon, 1984.

PRATT, C.; WARNKEN, J.; LEEMING, R.; ARTHUR, M. J.; GRICE, D. I. Degradation and responses of coprostanol and selected sterol biomarkers in sediments to a simulated major sewage pollution event: A microcosm experiment under subtropical estuarine conditions. Org. Geochem., v. 39, n. 3, p. 353-369, 2008.

PUERARI, L.; CARREIRA, R. S.; NETO, A. C. B.; AlBARELlO, L. C.; GAllotTA, F. D. C. Regional assessment of sewage contamination in sediments of the Iguaçu and the Barigui Rivers (Curitiba city, Paraná, southern Brazil) using fecal steroids. J. Braz. Chem. Soc., v. 23, n. 11, p. 2027-2034, 2012. 
SHAH, V. G.; DUNSTAN, R. H.; GEARY, P. M.; COOMBES, P.; ROBERTS, T. K.; VON NAGY-FELSOBUKI, E. Evaluating potential applications of faecal sterols in distinguishing sources of faecal contamination from mixed faecal samples. Wat. Res., v. 41, n. 16, p. 3691-3700, 2007.

SIMONEIT, B. R. T. Characterization of organic constituents in aerosols in relation to their origin and transport: a review. Int. J. Environ. Anal. Chem., v. 23, p. 207-237, 1986.

SUGUIO, K. Introdução à sedimentologia. São Paulo: Edgard Blucher/Edusp, 1973. 317 p.
VENKATESAN, M. I.; KAPLAN, I. R. Assessment of fecal sterols and ketones as indicators of urban sewage inputs to coastal waters. Environ. Sci. Technol., v. 24, n. 2, p. 208-214, 1990.

VENKATESAN, M. I.; MIRSADEGHI, F. H. Coprostanol as sewage tracer in McMurdo Sound, Antarctica. Mar. Pollut. Bull., 25, 328-333, 1992.

VOLKMAN, J. K. Sterols and other triterpernoids: source specificity and evolution of biosynthetic pathways. Org. Geochem., v. 36, n. 2, p. 139-159, 2005. 